\title{
Playful Hyper-responsibility and the Making of a Performing Audience
}

\author{
Åkerstrøm Andersen, Niels; Knudsen, Hanne
}

\author{
Document Version \\ Final published version \\ Published in: \\ Soziale Systeme \\ DOI: \\ $10.1515 /$ sosys-2014-0212 \\ Publication date: \\ 2015 \\ License \\ CC BY-NC-ND
}

Citation for published version (APA):

Ákerstrøm Andersen, N., \& Knudsen, H. (2015). Playful Hyper-responsibility and the Making of a Performing Audience. Soziale Systeme, 19(2), 433-455. https://doi.org/10.1515/sosys-2014-0212

Link to publication in CBS Research Portal

\section{General rights}

Copyright and moral rights for the publications made accessible in the public portal are retained by the authors and/or other copyright owners and it is a condition of accessing publications that users recognise and abide by the legal requirements associated with these rights.

\section{Take down policy}

If you believe that this document breaches copyright please contact us (research.lib@cbs.dk) providing details, and we will remove access to the work immediately and investigate your claim.

Download date: 26. Apr. 2023

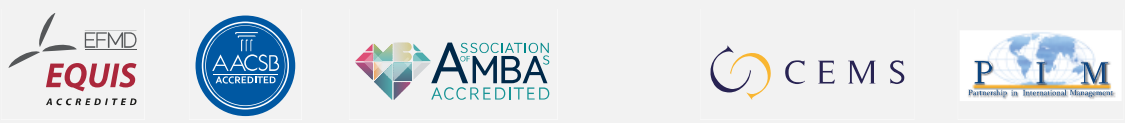




\title{
Playful Hyper-Responsibility and the Making of a Performing Audience
}

\section{Niels Akerstrom Andersen and Hanne Knudsen}

Journal article (Publishers version)

\begin{abstract}
Cite: Playful Hyper-Responsibility and the Making of a Performing Audience. / Akerstrom Andersen, Niels; Knudsen, Hanne. In: Soziale Systeme, Vol. 19, No. 2 , 2015, p. 433-455.
\end{abstract}

DOI: http://dx.doi.org/10.1515/sosys-2014-0212

Uploaded to Research@CBS: August 2016

(C) 2016. This manuscript version is made available under the CL-BY-NC-ND 4.0 license http://creativecommons.org/licenses/by-nc-nd/4.0/ 


\section{Playful hyper-responsibility and the making of a performing audience}

Abstract: The citizen is currently presumed to lack both the will to take responsibility and the imagination to see what his or her responsibility may include. This »lack of responsibility « becomes an object of intervention because function systems see themselves as depending on the citizens: The educational system sees itself as depending on the student to succeed in creating learning; the health system sees itself as depending on the patient to succeed in promoting health. Responsibility games are one method used to make citizens responsible. In this paper we argue that these games and other present welfare politics striving to increase personal responsibility do not simply increase responsibility, they have at least two important effects: 1 . With responsibility games personal responsibility is no longer presumed, and the form of personal responsibility is dislocated into a form of playful hyper-responsibility. To be recognized as responsible, the citizen should go second order and reflect on and investigate his/her potential responsibilities. 2 . Responsibility games redistribute the roles in the function systems as the traditional distinction between performance roles (e. g. doctor or teacher) and audience role (e.g. patient or student) is challenged by a new hybrid, »the performing audience«. The citizen is both an object of treatment and investigation, - with the professional as the expert - , and a performer, regarding $\mathrm{him} /$ herself through the eyes of the system in order to take responsibility.

\section{Introduction}

I knew only one duty, that attending to my school and in this respect I was left entirely to my own responsibility ... I was exempted from all parental twaddle. He never asked me about my lessons, never heard me recite them, never looked at my exercise book, never reminded me that now it was time to read, now time to leave off, never came to aid of the pupil's conscience, as one sees often enough when noble minded fathers chuck their children under the chin and say, >You had better be doing your work.< When I wanted to go out he asked me first whether I had time. That I was to decide for myself, not he, and his query never went into details. That nevertheless he was deeply concerned about what I was doing I am perfectly certain, but he never let me observe it, in order that my soul might be matured by responsibility. (Kierkegaard 1946: 225)

This passage appears in Either/Or, published in Copenhagen in 1843 by Søren Kierkegaard, who is generally considered the founder of existentialism. His father, we are told, expected personal responsibility of the son, but the fa- 
ther never fully articulated this, just as he did not announce any expectations about specific actions and decisions. By this means, the father avoided turning the son's sense of responsibility into a sense of duty, something that would be defined somewhere outside him.

Over 160 years later, in May 2008 the Danish government extended an invitation to an open conference about "personal responsibility" to participants from sbroad parts of our society. Seven Danish ministers published an article with the headline: „Community builds on personal responsibility«. In the article they write: »The individual citizen has a responsibility to the community - but the community must never be an end in itself or grow so large that it takes away freedom and releases the individual from personal responsibility. We must put demands on ourselves and each other. We must expect something, and we must have the courage to raise the question: What have you done yourself? (Hedegaard/ Jespersen / Mikkelsen et al. 2008) In the two years following the conference, a number of games were created by Danish ministries with the aim of increasing personal responsibility among citizens. The idea was that these games should be played by citizens supervised by welfare professionals.

Kierkegaard's father, according to the text, played responsibility into his son, never making his concrete expectations explicit. More than 150 years later, the Danish state takes the position of the father and invites citizens to play with personal responsibility in games of its design. The country that gave us existentialism, we might say, now turns responsibility into a game.

In this article, we investigate how the form of personal responsibility is put at stake in policy programs within welfare institutions directed to increase personal responsibility. We believe that personal responsibility does not simply increase as a result of these programs. The very logic of the form is somehow challenged when personal responsibility is to be demonstrated in public games and dialogues. And the question is: What is the new form of hyperresponsibility a functional answer to?

There are four parts in our article. In the first part, we consider how function systems observe responsibility, and how these observations are linked to distinctions between performance role/audience and role/person. In part two, we argue that, in order for a system to receive ascribed responsibility, it already needs to always be personally responsible. With help of Derrida we analyze the form of responsibility and its inherent paradox. In part three, we give examples to show how the semantic of responsibility has changed and we link this to a rather new re-entry of the distinction performance role / audience, constructing what we have called a performing audience. Finally, we discuss how this change in the semantics of responsibility challenges the form of personal responsibility constructing what we call playful hyper-responsibility. 


\section{Ascribed responsibility}

We take our point of departure in Luhmann's description of modern society as a functionally differentiated society. In the perspective of Luhmanian systems theory, function systems such as economy, politics, law, and health always operate with a distinction between so-called performance roles and audience roles, for example, doctor/patient, lawyer/client, politician/voter, and teacher/student. The distinction marks very different ways of addressing expectations and responsibilities to individuals (systems). Rudolf Stichweh $(1997,97)$ writes about this relationship as follows: »The concept of inclusion means that all those members of society who are not involved in the operations of a function system via performance roles are nonetheless important as a public of this function system. That is there are specific roles for members of the respective public: roles for voters, consumers, sports spectators, and religious laypersons«.

According to Niklas Luhmann (1990, 178-179), an audience is always an audience to a system. A patient is only a patient observed as such by the health system. An audience is first of all an internal construction within the function system, a construction that only offers a very limited role script (Stäheli 2003). It is not a position from where one is able to perform directly into the key operation of the function system (perform treatment, teaching or legal decisions). Though one is primarily offered the position of an observer, the audience has to perform in order to create necessary premises for the function system to work. The voters have to pay interest in the political debate, knowing the programs of the political parties, so it takes quite an effort to prepare for voting. In the educational system the teacher performs by teaching but the students as audience have to listen, to behave, to ask and answer questions, and they have to prepare for the lessons, doing their homework. One of the most common comments at parents' conversations is that the pupil ought to be more active during lessons and put up his or her finger. This is not a request for the student to start teaching, though, but to perform more actively as audience. So a distinction is drawn between performance roles and audience roles, and an individual addressed by a performance role will most likely be recognized as a person when the individual accepts the packages of expectations condensed in the role. This recognition means that the individual is presumed to have professional competences, systemically relevant point of views, and the personal capacity of judgment and responsibility regarding systemic issues. The individual who is addressed by the audience role will on the other hand never be fully recognized as a person, but more as an element in a passively observing audience belonging to the mass. The patient is more a category than a person. When a doctor asks a patient questions, the doctor is gathering symptoms, preparing a diagnostic decision. The doctor is not interested in the personal view of the patient regarding his illness. The patient contributes with informa- 
tion but not with a view on the diagnosis. The patient's personal speculations are precisely speculations and just noise to the medical communication. So the patient is traditionally addressed as an audience, and therefore not observed as a person, but merely a mass category. We have formalized it like this:

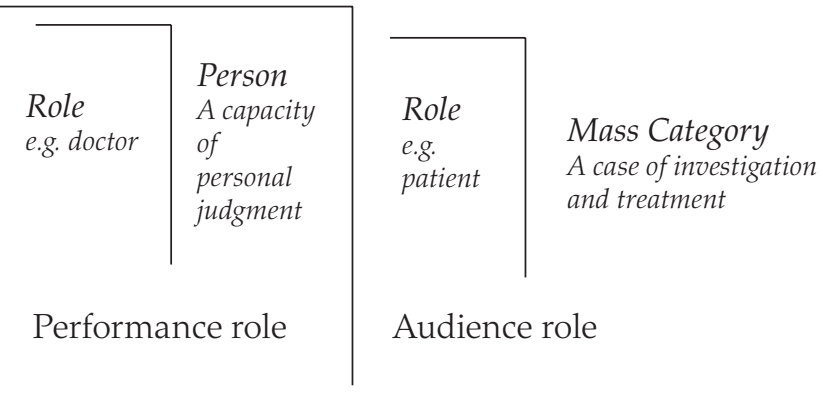

Figure 1: The distinction between performance role and audience role drawn by a function system

Being addressed as a professional with a performance role or as one in the audience makes a difference for the kind of responsibility you are ascribed, and the responsibility is of course relative to the function systems observing the responsibilities. It might roughly be described like this.

\begin{tabular}{|l|l|l|l|l|}
\hline $\begin{array}{l}\text { Function } \\
\text { system }\end{array}$ & $\begin{array}{l}\text { Performance } \\
\text { role }\end{array}$ & $\begin{array}{l}\text { Performance } \\
\text { responsibility }\end{array}$ & $\begin{array}{l}\text { First order } \\
\text { public role }\end{array}$ & $\begin{array}{l}\text { Audience } \\
\text { responsibility }\end{array}$ \\
\hline $\begin{array}{l}\text { The pedagogi- } \\
\text { cal system }\end{array}$ & Teacher & $\begin{array}{l}\text { Teaching } \\
\text { responsibilities }\end{array}$ & Student & $\begin{array}{l}\text { To be ready to } \\
\text { learn and do } \\
\text { homework }\end{array}$ \\
\hline $\begin{array}{l}\text { The political } \\
\text { system }\end{array}$ & Politician & $\begin{array}{l}\text { Political } \\
\text { responsibility } \\
\text { for the society }\end{array}$ & Citizen & $\begin{array}{l}\text { Citizen duties } \\
\text { and voting }\end{array}$ \\
\hline $\begin{array}{l}\text { The care } \\
\text { system }\end{array}$ & Social workers & $\begin{array}{l}\text { Responsibility } \\
\text { for diagnosing } \\
\text { the need for } \\
\text { help and prop- } \\
\text { er intervention }\end{array}$ & Client & $\begin{array}{l}\text { Ask for help } \\
\text { and receive the } \\
\text { help offered by } \\
\text { the system }\end{array}$ \\
\hline $\begin{array}{l}\text { The health } \\
\text { system }\end{array}$ & Doctor & $\begin{array}{l}\text { Medical } \\
\text { responsibility } \\
\text { regarding treat- } \\
\text { ment and pain } \\
\text { management }\end{array}$ & Patient & $\begin{array}{l}\text { Answer ques- } \\
\text { tions and re- } \\
\text { ceive treatment }\end{array}$ \\
\hline $\begin{array}{l}\text { The economic } \\
\text { system }\end{array}$ & Producer & $\begin{array}{l}\text { Economic } \\
\text { responsibility }\end{array}$ & Consumer & $\begin{array}{l}\text { Be informed } \\
\text { and rational }\end{array}$ \\
\hline
\end{tabular}

Figure 2: Role and responsibilities as seen by function systems 
Roles are distinct from persons. Roles are general motives disconnected from personal motives (Luhmann 1996). The roles define the responsibilities ascribed to persons. Persons are semantic tricks in the communication constituting a unity of action and experience. As semantic tricks they are addresses in the communication making ascriptions to systems possible and in the same operation construct the addressed systems as if they were actors. As semantic tricks persons are also collages of expectations (Luhmann 1995, 315-317). The more diverse and complex the set of expectations, the more the system will be observable as a person in the communication.

But if responsibility is to be attributed, does it then not require the expectation that this responsibility is received responsibly? It is not enough that one is conceived as a person. A personal responsibility is also expected. We think that role responsibility has to presume a personal responsibility, which is outside the role and which cannot simply be reduced to the role. What is the form of this responsibility? And what does the systemic responsibility look like from the point of view of personal responsibility?

Both in the case of performance role and audience role, personal responsibility is presumed by the function systems as a »constitutive outside«, necessary for the function of roles but unmarked and incommunicable in the systems. Through the distinction role/person, the system is able to distinguish between system motivation and personal motivation, observing the latter as irrelevant for the system. You might have personal motivations to become a doctor, for example. What matters for the health system, however, is that you are binding yourself to the generalized motivation defined in the role (Luhmann 1996). On the other hand, personal responsibility is presumed as a condition for binding yourself to the roles of the system and translating role obligations to personal commitments. Personal responsibility, in this view, exists mainly as an unarticulated presumption regarding performance roles and has very little to do with audience roles.

\section{The form of personal responsibility}

We need a description of the form spersonal responsibility<. Personal responsibility is not a very obvious thing to focus on within a systems theoretical framework. There are mainly two ways in which Niklas Luhmann discusses responsibility. The first way is as a moral, coded in the scheme esteem/disdain. Luhmann makes us aware that the moral code is asymmetric in the sense that communicating disdain involves a higher connectivity than communicating esteem. Moral communication, then, has a tendency to produce conflicts (Luhmann 1993). When personal responsibility is regarded as moral, Luhmann (1987) does not put a lot of hope into it. As he writes in Social Systems: »Morality becomes a disturbance factor (...) and must be kept in check« 
$(1995,240)$. The second way has to do with the creation of fictions of persons and actors. Luhmann writes about the attribution of responsibility as a mechanism for creating addresses in communication. Thematising an event as an action and attributing the responsibility for the action to a specific system constructs this system as an actor in the communication (1995, 165-166). This is a limited concept of responsibility restricted to attribution processes, and leaves out personal responsibility and questions about how responsibility is presumed to be received. So in order to study how personal responsibility might be put at stake in recent developments we must begin theorizing on the more general form and function of personal responsibility in a functionally differentiated society.

So we have to look closer at the form of personal responsibility. Through which distinction is it operating? And what kind of communicative paradox does it constitute? What, then, is the presumed form of personal responsibility? How is personal responsibility observed and communicated? How does the concept of responsibility carry certain expectations?

Let us return to Kierkegaard's observations on this point: »Duty is the universal which is required of me; so if I am not the universal, I am unable to perform duty. On the other hand, my duty is particular, something for me alone, and yet it is duty and hence the universal. ... for I can do duty and yet not do my duty, and I can do my duty and yet not do duty« (Kierkegaard 1946, 221). Kierkegaard is aware that it is not possible to fulfill the expectations that are condensed in the form of personal responsibility by living up to the general expectations in one's surroundings regarding responsibility. Personal responsibility, we might say, is our own responsibility. It cannot be derived from norms, rules and ethics. Your responsibility is only yours and should not respond to others. Kierkegaard makes us also aware, that if we expect responsibility of others we have to hold it back, not making expectations too explicit.

While Kierkegaard has a theological interest in answering what responsibility is, Derrida goes second order in observing responsibility as a language game folding out certain logic. He states that the possibility of responsibility begins in the impossibility of responsibility $(1992,24)$. The expectations condensed in the concept of personal responsibility is split into two incommensurable forms that yet have to be connected: The general responsibility with its ethics, norms, and rules obliging everybody in any situation; and absolute responsibility where you are expected to stand alone with the responsibility, respond to no one but yourself, and where you cannot simply follow the common rules or norms.

We observe both the general and the absolute responsibility as communicative expectations and not as something going on in the psychic system. They are two sides of a difference drawn in the communication with higher connectivity on the marked side (general responsibility) than on the often un- 
marked side (absolute responsibility). Personal responsibility is the unity of the difference.

The general responsibility is where one has to account for one's action in relation to expectations in one's environment. The general responsibility consists of ethics, rules, and norms. General responsibility is similar to that discussed above as the function systems' ascription of responsibilities. You are responsible when you respond to the other and you are held accountable to the other. The problem is how is it possible to respond to one without sacrificing the many? In systems theoretical terms: When all or many of the function systems make claim on your responsibility. You are always addressed by a surplus of general responsibilities. You can simply not respond to all calls of responsibility.

So the problem is that you have to sacrifice some responsibilities to fulfill other responsibilities. How do you do that in a responsible way? That is what absolute responsibility is about. In the absolute responsibility, the expectation is, you stand all by yourself. It is a singular responsibility nobody can replace. One cannot take or carry the responsibility of another: »But what is also implied (in the absolute responsibility) is that, by not speaking to others, I don't account for my actions, that I answer for nothing [que je ne réponde de rien] and to no one, that I make no response to others or before others. It is both a scandal and a paradox « (Derrida 1992, 60). Your responsibility is not a response to any explicit demand: »Secrecy is essential to the exercise of this absolute responsibility as sacrificial responsibility« (67). You cannot explain your choice through a reference to general rules; it is your decision and cannot be explained.

The two forms of responsibility are incommensurable, because you can only carry the absolute responsibility by rejecting your general responsibility. Yet, if you should take your personal responsibility, you have to take both the absolute responsibility and the general responsibility. You have to take both forms of responsibility and at the same time they exclude each other. The personal responsibility as a unity of absolute and general responsibility is constituted as a paradox, where one is only absolutely responsible if one is at the same time generally irresponsible: »As soon as I enter into a relation with the other, I know that I can respond only by sacrificing ethics, that is, by sacrificing whatever obliges me to also respond, in the same way, in the same instant, to all others.« $(1992,68)$

The result is a re-entry of the two sides of responsibility on the absolute side of the distinction: You are then only personally responsible if you are both absolutely and generally responsible in an absolute and singular manner. We have formalized the expectation structure of personal responsibility like this: 


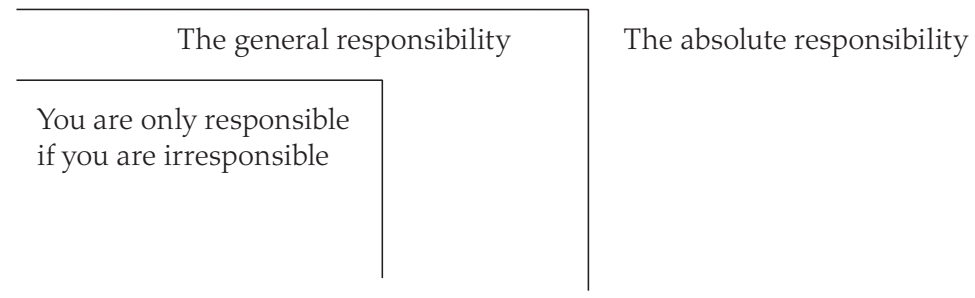

The form of personal responsibility

Figure 3: The form of personal responsibility

Every concrete responsibility, every concrete decision that strives to become responsible has to get out of this paradox, not by solving it, but through deparadoxification, making the impossible look possible. It has to refer to the general in a personal way, hiding the reference. Ethics (general responsibility), says Derrida $(1992,62)$, is a temptation that the absolute responsibility has to resist: »The ethical therefore ends up making us irresponsible. It is a temptation, a tendency, or a facility that would sometimes have to be refused in the name of responsibility that doesn't keep account or give account, neither to man, to humans, to society, to one's fellows, or to one's own. Such a responsibility keeps it secret; it cannot and need not present itself «.

This is what is presumed but not prescribed by the function systems. They can and do prescribe roles: performance roles presuming a large amount of personal responsibility; and audience roles presuming almost no personal responsibility, observing the individual as a mere category. But the function system cannot prescribe personal responsibility as that would be to cancel the distinction between role and person, and tempt the responsible subject with rules and ethics, succumbing, that is, to pure general responsibilities.

To attribute a responsibility to a system in the form of general expectations involves the expectation that there is also an absolute responsibility which remains unmarked. The classical form of personal responsibility involves a paradox, an impossibility. This paradox has up to now been handled by ignoring it. With the current ambitions of increasing responsibility, the communication also gets an ambition of knowing what goes on in the psychic system, inside peoples' brains. As this is impossible, what happens is that the absolute part of the responsibility is drawn from the unmarked to be marked - and thereby becomes part of the general responsibility.

\section{Responsibility games}

We now take a closer look at a number of responsibility games designed precisely to increase personal responsibilities. We also show how the paradox of inviting the patient/client/student/parent to not only be passive but also ac- 
tive in taking responsibility for creating him/herself in the gaze of the particular function system (health, care, education) has some strange effects in dislocating the very concept of "personal responsibility«.

In Denmark responsibility games emerge from around 2000 in a number of welfare areas simultaneously. They represent a new layer of responsibility semantic, and although we will not give a larger historical analysis here, a brief resume of earlier studies in the history of responsibilisation semantic might be of value. From around 1900 up to today, we can broadly distinguish four phases of responsibility and responsibilisation of citizens (Knudsen 2010; Knudsen / Andersen 2014):

\begin{tabular}{|l|l|l|}
\hline & Concept of responsibility & Technology \\
\hline $\begin{array}{l}\text { The citizen as } \\
\text { subject of law }\end{array}$ & $\begin{array}{l}\text { Responsibility is split into a formal } \\
\text { responsibility and a presumed personal } \\
\text { responsibility }\end{array}$ & $\begin{array}{l}\text { Rules } \\
\text { Prohibitions }\end{array}$ \\
\hline $\begin{array}{l}\text { The citizen as } \\
\text { receiver and } \\
\text { supporter of } \\
\text { welfare }\end{array}$ & $\begin{array}{l}\text { Formal responsibility is supplemented with } \\
\text { a substantial responsibility articulated } \\
\text { by experts. Personal responsibility is still } \\
\text { presumed, but now enlightened through } \\
\text { advice }\end{array}$ & $\begin{array}{l}\text { Advice } \\
\text { Guiding supervision } \\
\text { Concrete suggestions }\end{array}$ \\
\hline $\begin{array}{l}\text { The active } \\
\text { citizen }\end{array}$ & $\begin{array}{l}\text { Personal responsibility is no longer pre- } \\
\text { sumed. The public administration doubts } \\
\text { the will of citizens to take responsibility. } \\
\text { It becomes a question of how to take } \\
\text { responsibility for the responsibilisation of } \\
\text { the single citizen }\end{array}$ & $\begin{array}{l}\text { Unilateral organized } \\
\text { dialogues } \\
\text { Empowerment } \\
\text { Citizen contracts }\end{array}$ \\
\hline $\begin{array}{l}\text { The citizen as } \\
\text { a potentiality }\end{array}$ & $\begin{array}{l}\text { The expectation is now an unlimited } \\
\text { responsibility including a responsibility } \\
\text { for investigating and searching for } \\
\text { potential responsibilities }\end{array}$ & Responsibility games \\
\hline
\end{tabular}

Figure 4: Semantic of responsibility

In the semantic of the citizen as a subject of the law, a difference is drawn between formal responsibility and personal responsibility. Formal responsibilities are general but clearly delimited. For example, a formal responsibility might be the duty to send your children to school. Personal responsibility is precisely personal and outside the boundary of the state. The public administration can appeal to the single citizen by formalizing duties, but it is up to the individual to decide to follow or not follow the rules, and to take the legal consequences.

In the welfare semantic, every function system connected to the welfare state develops its own substantial expert ethics, giving good advice and guidelines. Personal responsibility is still presumed, but it is articulated that the citizens 
sometimes lack the knowledge to act responsibly. The advice here is typically very specific and concrete. It might be about when to put children to bed, or about what makes a good healthy meal.

The concept of active citizenship is articulated in the late 1980s. With this concept the ideal becomes a citizen who searches for responsibility and takes responsibility for himself and others in the name of the community. And the different function systems often articulate disappointments. They begin not to trust the single citizen's will and capacity for responsibility. They begin to talk about empowerment of the citizen and to develop citizen contracts and partnerships.

Finally, today the citizen is observed as a potentiality, and the problem is not simply the lack of will, but also the lack of imagination and sensitivity towards possible responsibilities. In 2008 Karen Jespersen, Minister for Social Welfare, posed the following question to parents of schoolchildren: »Your child's friend is not happy because his parents are getting a divorce. Do you talk to the parents about this, or do you think that you should keep clear and leave the school teacher to deal with the problem? « At one and the same time, the question suggests that the parents' responsibility is without limits and that the responsible subjects (the parents) need to be guided to see what responsibility is expected of them. In another text the same Minister states that »We are faced with an enormous task: how to strengthen and sustain a fundamental sense of duty in relation to the upbringing of one's children and to take responsibility for what takes place in our preschools and schools. «It is not assumed that citizens are equipped with a fundamental sense of responsibility and dutifulness; training citizens to take responsibility is regarded as the responsibility of the state. And this is where responsibility games come in (Knudsen 2010; Knudsen / Andersen 2014).

We understand play as a particular form of communication, splitting the world in play and reality, saying »this is play, pay attention to the play, and let us play with the categories of reality«. So the reality observed through the form of play, is all the social and cognitive categories and frames you can play with, and through play, the contingency of the social becomes visible (Bateson 1955; Baecker 1999; Andersen 2009). We understand games as programs of playing, and responsibility games are then particular programs of playing. Often concrete responsibility games are somehow heterogeneous and not pure programs of playing, but simultaneously programs of teaching and governing, leaving it rather open how they actually will be played and with what mixed effects.

In Denmark responsibility games are widely designed and used in several welfare sectors such as health, social care, unemployment, family policy and education. Before looking in detail at a single case, we'll give some examples, which illustrate their distribution and variations. In the labor market, policy games are used to build up individual capacity of will and responsi- 
bility among the unemployed. In one of the games, unemployed people are encouraged to build themselves in Lego bricks. One of the unemployed who participated in such a game says: »I think that people see me as friendly, loyal, and honest. But in my Lego-identity model, we can see me as passionate and loyal, strong and disciplined, knowing where I am coming from and where I am going. A model can say a lot more about you than you can say about yourself. Building the model helped to see what person you really are. I chose the elephant to show that I am a stronger person than what others thought of me« (http://www.artlab.org.uk/legofieldwork.htm). This game is linked to a concept called »LEGO serious play«, which Lego says »... uses LEGO bricks and elements and a unique method where people are empowered to »think through their fingers « - unleashing insight, inspiration and imagination" (http://www.seriousplay.com/8326/THE\%20EXPERIENCE).

Games are also widely used in schools to increase personal responsibility for the class community among the students. One of these games is called Short and Sweet in introductory education. The game uses cards and is described as a social-pedagogical conversation game. There are happy cards (-) and unhappy cards $(:)$, and the children take a card in turn. The child reads from the card and then has to pass the card on to another child who the first child believes the card to represent. For example, a happy statement could be »I pay attention to your actions«. An unhappy card could read »You often disrupt class when we sit in a circle«. Each card begins a conversation among the children. The classroom teacher is assigned the role of game master, who has the right to raise questions that might guide the conversation along. A question could be: »Why do you think you were given this card by xxx?« Once all the cards have been dealt, there is a so-called re-working of the game. Not all players have necessarily received a card and there might be an uneven distribution of happy and unhappy cards. The game guide stresses the fact that the game is a »conversation game in which everyone is a winner «. However, even if everyone wins, some of the players probably perceive and express themselves more as winners than others. Therefore, the re-working of the game raises questions such as »How did it feel to receive this card?«, »Do you feel that the cards were distributed in an appropriate way?«, and »Did anyone feel like revenging themselves when they received a bad card?« (Andersen 2009). The aim of the game is to make the students take responsibility for themselves, their learning community and their position in the community.

A third example, called The Game of Responsibility, also comes from the school system but addresses families. The objective of the responsibility game is described as making visible the expectations between school and home with respect to practical arrangements, emotional relationships, and interpersonal relations.The parents are divided into groups. On the table is a game board as shown below: 
5 Distribution of responsibility

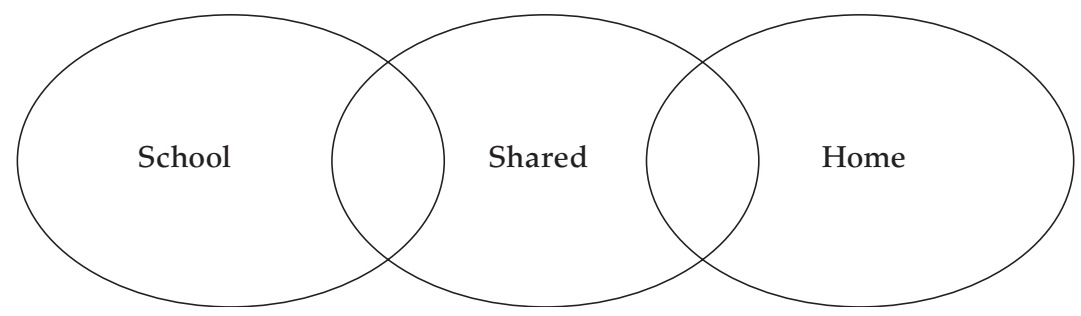

Figure 5: Mapping responsibility

On the table is also a stack of 32 cards, each of which describes a responsibility in relation to the child. The questions on the cards read: Who is responsible for making sure: »That the child learns?", »That the child likes to go to school?«, $»$ That the child learns that a deal is a deal?«, or »That the child learns to take responsibility?«. The responsibility game is divided into three rounds. During the first round, the parents draw cards from the stack and answer whether the responsibility pertaining to their specific question should be placed in the home, in school, or whether it is a shared responsibility. In the second round, the group prioritizes the three most important cards for shared responsibility between school and home. Then the group discusses what the respective contributions of the school and the parents could be in cooperating on the three selected questions.The third round takes place in the plenum where the groups present their proposals for a division of responsibility between school and home (Knudsen 2011; Knudsen / Andersen 2014).

In the following, we go into more details with one example to see how responsibility games actually work.

\section{$6 »$ Health at play«: a case}

In 2007, the National Board of Health and the Danish Veterinary and Food Administration with the School and Society organization published the game Health at play - dialogue and cooperation about health in the school. The purpose of the game is to initiate dialogue about health in schools and to formulate and agree on the issues of food and meals, exercise, drugs, well-being, knowledge, and attitudes.

The game is based on a rather ambitious health ideal that intervenes in almost all aspects of life. The game refers to this ideal as a "positive concept of health « defined in opposition to other conceptions, which merely concern the prevention of sickness. Health is said to concern lifestyle, living conditions, quality of life, physical well-being, psychological well-being, and social well-being. This definition of health leaves no aspect of life to be defined outside the domain of 
health policy. Life in all its facets becomes a health concern. The introduction to the game says: »All these areas represent important elements of a healthy life and are of equal importance in the dialogue «.

The game comes with a short presentation video, which can also be found on the National Board of Health's website. The video includes interviews about the game with different stakeholders. In the video, a health consultant for Gladsaxe Municipality says: »As a municipality, we could simply and singlehandedly define the framework for defining health, but it is important that both parents and students are able to recognize themselves so that it is not only something they engage in while in school but something they carry over into their lives at home.« Making citizens express what they mean by the concept of health is seen as a way to produce personal responsibility. Through this campaign, parents and students should learn to recognize themselves as more or less healthy and work for their own health both at school and at home. So health responsibility is not presumed among the citizens. Public definitions of health are not expected to work because a responsible receiver is not expected at the starting point - but is to be »created «.

The video then goes directly to a consultant, who says: »The question is not whether we should all live the same way; whether we should all have the same preferences. In a diverse society, it is important that there is room for differences «. This is the regulation problem in a nutshell, which is what Health at Play is supposed to provide a response to. There is a wish to regulate what takes place in the home so that home activities can be perceived as healthy. At the same time, however, it is not possible to articulate this regulatory ambition without generalizing health, canceling differences of individual lives and violating the idea of personal responsibility. Play becomes a way of inviting citizens as an audience to take personal responsibility for health and thereby become individuals in the health system.

Health at Play is intended for use in the context of events for parents, pedagogical days, or events for older students. It takes approximately two hours to play. The game is instructed by a teacher and is set up by dividing parents into groups of four to six, seated at different tables. On each table, there is a game board with three spaces entitled »agree«, »partially agree«, and »disagree«. Clearly, the agenda is about regulating consensus.Each of the groups is given a stack of statements. Some of these are:

- It is not okay for students to try alcohol at home.

- Exercise and play need to be incorporated into classes other than just physical education.

- Students need knowledge, experience, and positive role models in order to choose healthy alternatives to soft drinks, candy, and chips.

- Parents are the children's most important role models.

- Parents are responsible for establishing a strong parent network in the class. 
- Children and young people need to be motivated to live a healthy lifestyle.

- Children and young people must learn to take responsibility for their own health.

The game instructions outline a structure for the course of the dialogue where the parents are invited to discuss and categorize the statements under the headline »Play«. A double suspension problematic is at work here. First: the statements are public statements, which do not want to look public but to become private statements >coming from within' the single parent. Second: the dialogue is one that does not want to look like one building up publicly binding norms. That is why it is called a game; it is not binding, it is just for fun. Nevertheless, the statements invite the parents to investigate their attitudes to health in public and observe how other parents are observing them. The parents are not expected to have a capacity for health responsibility, but it is expected that by bringing private thoughts into public dialogue, personal responsibility is fostered. Obligations or rules are not explicit. Instead, playful dialogue becomes a kind of withdrawn normativity, a norm about a normative and playful public dialogue.

\section{HEALTH AT PLAY: Prioritization table}

FRUIT WATER VEGETABLES EXERCISE PLAY RESPONSIBILITY SELF-CONFIDENCE LIGHT CLASSROOM FRIENDSHIP HAPPINESS TRUST AIR

\begin{tabular}{|l|c|c|c|c|}
\hline & $\begin{array}{c}\text { Prioritized } \\
\text { statements }\end{array}$ & $\begin{array}{c}\text { Suggested } \\
\text { arrangements } \\
\text { for parents }\end{array}$ & $\begin{array}{c}\text { Suggested } \\
\text { arrangements } \\
\text { for pupils }\end{array}$ & $\begin{array}{c}\text { Suggested initia- } \\
\text { tives for the school } \\
\text { and management }\end{array}$ \\
\hline 1 & & & & \\
\hline 2 & & & & \\
\hline 3 & & & & \\
& & & & \\
\hline
\end{tabular}

Figure 6: Prioritization table, Health at play.

The game is divided into phases. First, the groups discuss the statements and classify them into the statements they agree with, disagree with, or partially agree with. Second, the group focuses on the statement cards that the group agrees with. The three statements are given a priority and the dialogue 
shifts towards suggestions for action for parents, students, and the school in response to the individual statements. These are written into a prioritization table (shown below). Suddenly, the whole dialogue shifts from game to decision. The groups now present their suggestions to each other, and the game instructor sums up the selected statements in a prioritization table, calling it a collective agreement, which is subsequently emailed to all participants »so that we all know which agreements have been reached.« The instructor suggests that the collective agreements should be evaluated at subsequent parent meetings.

One might question whether this qualifies as play. It is called a game, but it ends up as agreements. These agreements are surreptitiously brought in through the back door, and the game never encourages dialogue about whether agreements should be made in the first place. One could argue that it is a game in the sense that the agreements reached have been created in a way so that the communicative afterlife of the agreements obtains an oscillating quality, constantly oscillating between observations of the agreements as agreements and observations of the agreements as an agreement game.

On the level of play, parents and the school are parties to the agreement, facing each other as independent legal actors with the possibility of binding their own freedom. The game refers to »collective agreements«, which can be reached with parents as if they were one body or at least one collective legal actor rather than separate individuals. But the parents are not a collective body. That is a fiction within the game, a fiction that is nonetheless used as a power technology in relation to the individual parent who appears to be disloyal if he refuses to play the game. The whole game is based on the expectation that no individual parent is going to refuse to be part of the game. And why would any parent do so as long as it is simply a game? So everyone plays only to discover that the game is not a game but a negotiation and decision process. However, one is still unable to refuse to play because as soon as one says no, the negotiation process is going to return to simply being a game, and as part of a game there is no possibility for the parents' opinions to play a binding role. The game therefore produces the peculiar situation that it impossible to get out of the game even though one has voluntarily entered into it. Moreover, articulating the negotiation and decision process as a game or as play is a way of getting around the difficulty that the agreement cannot be sanctioned. Parent meetings are not an organization where parents are authorized to make binding decisions. Therefore, the school pretends to make collective decisions and emphasizes throughout the game the impression of consensus among parents, from which it will subsequently be difficult for individual parents to deviate.

What we would like to point out here in particular is the question of responsibility. As we mentioned, personal responsibility has to be personal; it presupposes the individual's free will. There are a number of characteristics about 
»Health at play« that do not call for the individual's free will: 1) It is an invitation to participate in a game but once in, you can not get out. 2) It is an invitation to take part in a dialogue that seems to be a public dialogue on norms, but turns out to be private statements >coming from within<. 3) It is a decision process articulated as a game.

Another interesting aspect of the agreements is that they do not only define specific obligations. In fact, the collective agreements outline obligations with respect to the self-creation of the families. The families commit to creating themselves in the image of a healthy family. Thus, the collective agreements mean not only a commitment of one's individual freedom, but also a commitment to a specific way of creating oneself as a free family. Therefore, one is not free until one has created oneself and one's family in a way so that one's lifestyle, living conditions, quality of life, physical well-being, and social wellbeing can be considered healthy (for the contractualization of the citizen: Andersen 2004; 2007; 2008).

\section{Toward a performing audience}

We shall now describe the governing ambitions in the analyzed games through the distinction performance role/audience role, claiming a re-entry of the distinction and the making of a »performing audience us to more precisely address the impossibilities embedded in the governing ambitions. The shift to what we have marked as "personal responsibility« results in a re-entry of the distinction we introduced between performance role and audience roles made by function systems. With the concept of »active citizenship « and »the responsibility searching citizen« new expectations are addressed to the audience. The audience is not simply expected to provide conditions for the professionals to be able to perform. The single individual in the audience are expected to operate on his / herself directly to produce the systems core task.

The audience is now observed as a sum of individuals, who have to be targeted individually (the citizen in center) and are expected to participate directly in the key operations of the systems e.g. teaching, treatment and care. This involves that the individual is expected to do things that only the professional used to be authorized to do. The student becomes directly responsible for his/her own learning, not only preparing for teaching but also teaching him/herself. This involves looking at him/herself in the code better/worse learning. The teacher should supervise the student to make an individual plan for his / her goals, homework, self-evaluation etc., but it is the student who is to be responsible for his/her own learning. As one of the current researchers and policy advisers within education states: »Teachers need to move from the single idea to multiple ideas, and to relate and then extend these ideas 
such that learners construct and reconstruct knowledge and ideas. It is not the knowledge or ideas, but the learner's construction of this knowledge and these ideas that is critical." (Hattie 2009, 239) The illustration is a photo of an eye and a text following the edge of the eye, with the »and « as the pupillary, stating: »When teachers SEE learning through the eyes of the student and When students SEE themselves as their own teachers.« (238) It becomes difficult to distinguish between the performing role and the audience role. The audience is expected to contribute directly to the creation of the core task of the system, not only providing premises for education.

Similar in the psychiatric hospitals, where patients are employed and considered equal to professionals regarding treatment of other mentally ill patients. They are considered experts in their own lives and professionals are instructed to respect their inputs and judgements. In social policy social workers are no longer to define the client's problem in a professional vocabulary and decide a relevant intervention. That is now considered problematic because the social workers are said to ssteak the problem from the clients. Instead problems are to be defined together with the client. The ideal is shelp to self-help<. The social worker and the client should ssee together, and make sure that the client takes ownership to the problem.

Self-responsibility is something different observed in the care system, the educational system etc. The common structure of these new expectations is that the individual addressed as audience has to observe herself in the code and language of the system. It is now expected of the audience that it creates itself as a multitude of individuals creating themselves in the image of the function system. We can talk about an audience role of second order when it is expected of the citizen to perform self-observation in the gaze and code of the function system (Andersen/Born 2005).What happens is a kind of re-entry of the distinction between performance role and audience role, creating the expectation of the sperforming audiences:

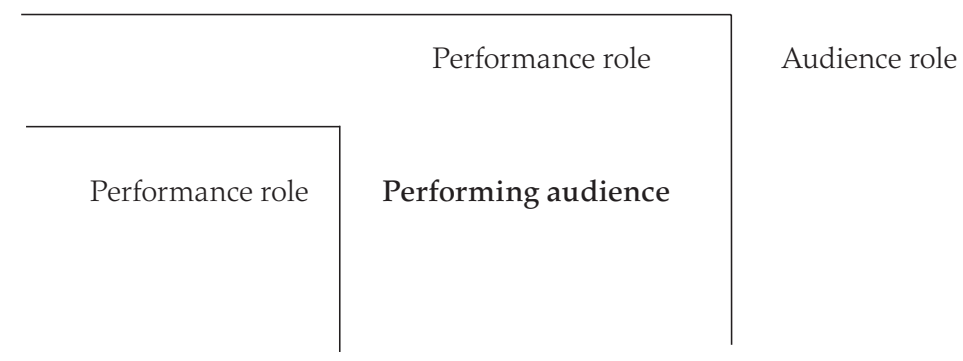

Figure 7: Audience role of second order

The student should contribute to his/ her own learning process. The patient must take part in the diagnosis and in the treatment of himself or herself. The client has to help herself etc. This argument is collected is the following table: 


\begin{tabular}{|l|l|l|l|l|l|}
\hline $\begin{array}{l}\text { Functional } \\
\text { system }\end{array}$ & Code & $\begin{array}{l}\text { Re-entry of } \\
\text { the code }\end{array}$ & $\begin{array}{l}\text { Perfor- } \\
\text { mance } \\
\text { role }\end{array}$ & $\begin{array}{l}\text { Audience } \\
\text { role }\end{array}$ & $\begin{array}{l}\text { Performing } \\
\text { Audience }\end{array}$ \\
\hline $\begin{array}{l}\text { The pedagogi- } \\
\text { cal system }\end{array}$ & $\begin{array}{l}\text { Better/ } \\
\text { worse } \\
\text { learning }\end{array}$ & $\begin{array}{l}\text { To learn how } \\
\text { to learn how } \\
\text { to learn }\end{array}$ & Teacher & Student & $\begin{array}{l}\text { Responsible } \\
\text { for own } \\
\text { learning }\end{array}$ \\
\hline $\begin{array}{l}\text { The political } \\
\text { system }\end{array}$ & $\begin{array}{l}\text { Power } \\
\text { superior/ } \\
\text {-power } \\
\text { inferior }\end{array}$ & $\begin{array}{l}\text { Power to } \\
\text { empower }\end{array}$ & Politician & Citizen & $\begin{array}{l}\text { Active fellow } \\
\text { citizen }\end{array}$ \\
\hline $\begin{array}{l}\text { The care } \\
\text { system }\end{array}$ & $\begin{array}{l}\text { Help/ } \\
\text { non-help }\end{array}$ & $\begin{array}{l}\text { Help to } \\
\text { self-help }\end{array}$ & $\begin{array}{l}\text { Social } \\
\text { worker }\end{array}$ & Client & $\begin{array}{l}\text { Self-helping } \\
\text { client }\end{array}$ \\
\hline $\begin{array}{l}\text { The health } \\
\text { system }\end{array}$ & $\begin{array}{l}\text { Healthy/ } \\
\text { sick }\end{array}$ & $\begin{array}{l}\text { Preventive } \\
\text { conduct of life }\end{array}$ & Doctor & Patient & $\begin{array}{l}\text { The healthy } \\
\text { citizen }\end{array}$ \\
\hline $\begin{array}{l}\text { The economic } \\
\text { system }\end{array}$ & $\begin{array}{l}\text { Pay/non- } \\
\text { pay }\end{array}$ & $\begin{array}{l}\text { Pay for others' } \\
\text { payments }\end{array}$ & Producer & Consumer & $\begin{array}{l}\text { The co-pro- } \\
\text { ducing } \\
\text { consumer }\end{array}$ \\
\hline
\end{tabular}

Figure 8: To create one self in the perspective of the system

An individualization is happening, and the client, the student, the patient are ascribed a certain status of person in the function system. But the audience as an environment construction in the function system is somehow kept intact. The addressed quality of categorized audience follows as the shadow of the individualized audience. As a self-treating patient, one is addressed as a person in a limited and fragile way. One is expected to observe oneself in the eye of the system, but nothing else. One should not interfere in the operations of the system. Commenting on the work and judgments of the doctor or teacher will be observed as an act of aggression, and is not welcomed. On the one hand, the audience is offered the possibility of status as a person performing in the system. On the other hand, you are at constant risk of falling back into the passive category again, if the function system cannot recognize its own operations in the self-reflections of the individual. The patient is now addressed both as person and as mass category. The active citizen is like Alice in Wonderland both inside and outside. The individualized audience ascribed personal responsibility becomes a monster symbolically linking that which cannot be linked; system and environment. The active citizen is invited within the function system under the condition that she stays outside (Knudsen 2010; 2011). The performing audience is expected to observe itself through the gaze of the function system and to take responsibility for acting according to the code of health, education, help, etc. But the performing audience is not expected to question the function system or to insist on having something rele- 
vant to say from somewhere outside the system, and therefore does not have the possibility to take personal responsibility.

The games allow the function system to oscillate between offering a performance role to the citizens and to turn them into pure observers without a will of their own. One moment they are invited to take personal responsibility for their own behavior concerning their own well-being, the next moment especially if they do not respond rappropriately< - what they say can be dismissed because what we do is just for fun.

\section{Hyper-responsibility}

Responsibility games are technology to make a performing audience, but responsibility games also put the form of personal responsibility at stake, creating a rather peculiar set of expectations. What is happening is a re-entry of the responsibility form, creating hyper-responsibility (see figure). General responsibility is doubled, and itself becomes a unity of a distinction. This distinction is drawn between a hypothetical and potentialized surplus of general responsibilities on the one hand, and on the other a hypothetical, emergent and singular absolute responsibility. The unity of this distinction is general responsibility in the form of an ethics of potentiality and play.

Responsibility games point to the fact that it is no longer possible to articulate stable general expectations about responsibility. It has of course always been the case that there is a surplus of general responsibilities. But now general responsibility is produced in such a way that it reflects this surplus. Welfare professionals reflect that they cannot take responsibility for what exactly the single citizen's responsibilities are. They demand undetermined and unlimited responsibility. Health responsibility, responsibility for learning, responsibility for self-help are each too much, too many things and too indeterminate to be articulated as stable rules, norms or clear advice. By their very nature, responsibility games indicate that general responsibility has become singular and bounded to temporary processes. So, in the games, welfare professionals do not take responsibility for defining specific general responsibilities. Instead they take responsibility for facilitating a process in which participants can investigate potential general responsibilities, and by marking this process »dialogue and play« the general responsibility is not highlighted as general but as temporary and singular. So we get an ethics of potentiality, which defines general responsibility as a reservoir of not yet potentialized responsibilities. What then is expected of absolute responsibility? Well, it is not simply expected to be a responsible decision and act. What is expected primarily is self-investigation of the possible relations between the absolute and the general, and when the general has become emergent and singular (on the temporal dimen- 
sion), the only possibility with regard to acting with absolute responsibility is to be playful and to take part in the responsibility games and dialogues. In the past, welfare authorities acted as experts, formulating answers, rules and norms - expecting individuals to be absolutely responsible. Now authorities experience that their answers cannot be formulated in a sufficiently general way - on the other hand they do not dare to leave the responsibility for health to individuals and their personal responsibility. Therefore they mark the personal responsibility that used to be unmarked. They aim at regulating personal responsibility, declaring it a public responsibility to create personal responsibility. This means the personal responsibility is both marked as a public matter and at the same time has to be presumed personal. We get a re-entry of the distinction, forming on its inner side a second order responsibility, an ethic of potentiality, investigating possible relations between general and absolute. And on the outer side of the distinction we get an as yet unmarked and incommunicable absolute responsibility.

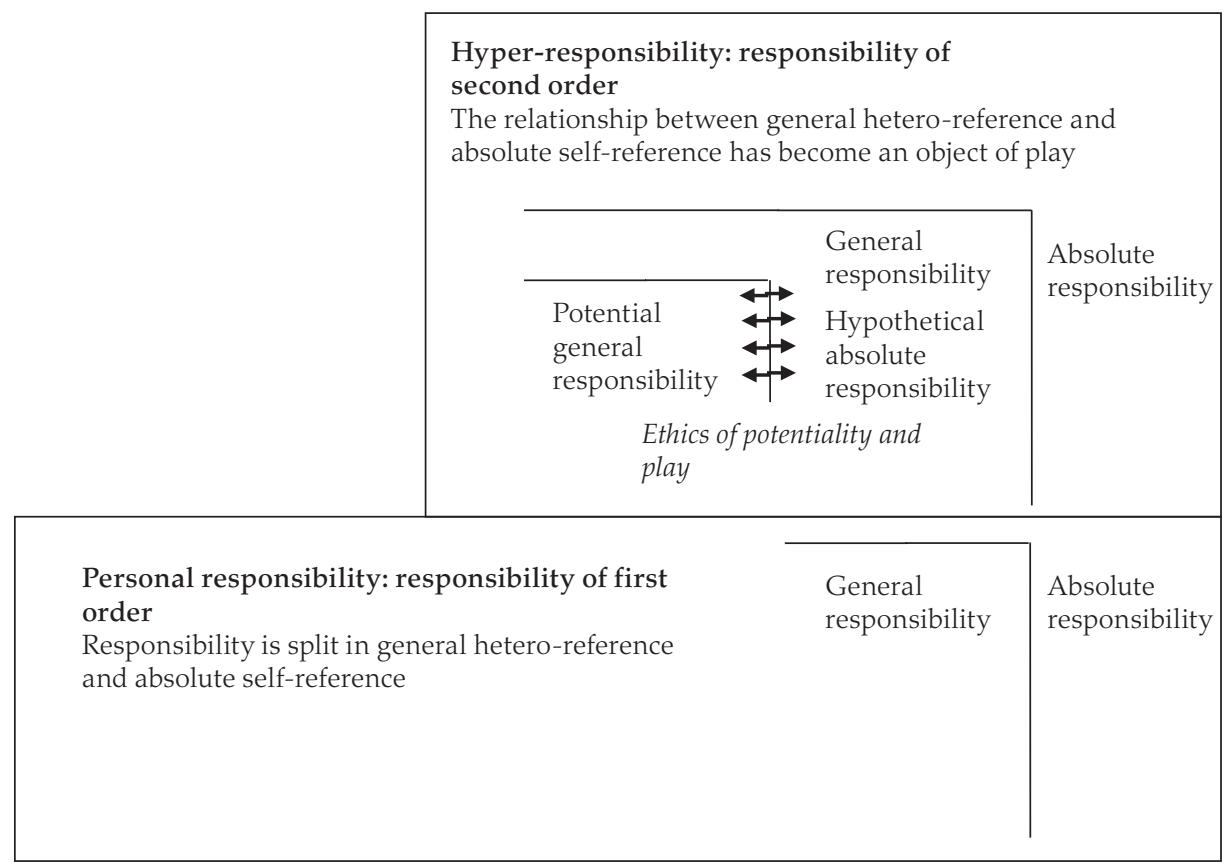

Figure 9: Hyper-responsibility

As this figure seeks to show, the form of hyper-responsibility is a new general responsibility defining responsibility as an investigation of potential responsibilities. So general responsibility goes second order. Ethics of potentiality and play is one of second order. This responsibility to investigate involves both an investigation of the reservoir of possible responsibilities and an investigation 
of potentially absolutely responsible ways to answer or not answer general responsibilities (the arrows). So the hypothetical absolute responsibilities in the form of potentiality become reflexive and second order. And all the time, an unmarked side of hyper-responsibility is always implied as the non-hypothetical absolute responsibility.

Does this form then lead to more or less responsibility? Our answer would be that hyper-responsibility simultaneously increases the possibility of personal responsibility and irresponsibility. At the same time as hyper-responsibility offers opportunities for investigating potential personal responsibilities it also increases contingency and uncertainty in the absolute choice making absolute responsibility even more difficult and unlikely.

\section{Conclusion}

The semantic of responsibility and responsibilisation has changed dramatically. First, responsibility took the form of law and rule. Then, with the early welfare state in the 1950s, responsibility took the form of expert advice. Both of these two first forms presumed the individual capacity for absolute responsibility. In the 1990s we talked about responsibilisation rather than just responsibility, and methods to gain responsibility took the form of citizens contracts and partnerships (Andersen 2004; 2007; 2008). Absolute responsibility was no longer presumed or trusted, it had to be encouraged. And, as we have focused on here, from 2000 onwards responsibilisation began to take the form of dialogical games and play. Not only is absolute responsibility not trusted, but individuals are observed as lacking both the will to take responsibility and the imagination of potential responsibilities in their specific situation and context (Knudsen / Andersen 2014; Knudsen 2010; 2011). An ethics of potentiality and play, a hyper-responsibility, appears as yet another expectation on the citizens. The citizens are not only expected to act responsibly; they are also expected to reflect in public on the limitless reservoir of possible responsibilities, and to investigate the potential ways to answer this limitless reservoir of potential responsibilities.

The story we tell is not simply a Foucauldian story of increased self-governance. More importantly it is a story about how function systems make themselves more dependent on the performance of their audiences. The patient or the student is not simply expected to leave the floor to the doctor or the teacher as the expert who knows what is the best for the patient/student. The doctor needs the patient to take responsibility for his own health, and the teacher cannot be successful unless the student takes responsibility for his own learning (Bjerg/Knudsen 2012). And in social work the client needs to take ownership of his problems while helping himself. The function systems observe that 
their performances depend on their audiences. A re-entry of the difference performance role/audience takes place, making up a figure of a performing and individualized audience. An audience invited to be the experts in their own lives. This is typically also related to a reflexive form of the codes. In the pedagogical system as an example the code, better/worse learning is re-entered when the program becomes to learn how to learn. In systems theory we are very aware that the pedagogical system can teach and educate, but it cannot control the learning of the single individual. Nevertheless modern schools emphasize learning as opposed to teaching. And this involves that they take responsibility for something they cannot control. Only individuals can learn. The pedagogical function system can only teach. When students are invited to take responsibility for their own learning, the function system makes its own performance depend on individual performances. It then becomes highly risky simply to presume individual capacity of personal responsibility.

So not only do we claim a new form of responsibilisation, we also claim that this responsibilisation is itself a symptom of new types of problems generated in the function systems. Hyper-responsibilisation is an answer to function systems that observe operations in their environment of psychic systems crucial to their own performances. Responsibility games are desperate tools designed to control what cannot be controlled, producing even more complexity and ambiguity.

\section{References}

Andersen, Niels Åkerstrøm/Born, Asmund W. (2005): Selvet mellem undersøgelse og bekendelse - En inklusions og eksklusionsmaskine. Grus 74,94-114.

Andersen, Niels Åkerstrøm (2004): The Contractualisation of the Citizen - on the transformation of obligation into freedom. Soziale Systeme 10, 2, 273-291.

Andersen, Niels Åkerstrøm (2007): Creating the client who can create himself and his own fate - the tragedy of the citizens' contract. Qualitative Sociology Review 3, 2, 119-143.

Andersen, Niels Åkerstrøm (2008): The World as Will and Adaptation: the inter-discursive coupling of citizens' contracts. Critical Discourse Studies 5, 1, 75-89.

Andersen, Niels Åkerstrøm (2009): Power at play. The relationships between play, work and governance. Palgrave Macmillan: London.

Andersen, Niels Åkerstrøm (2010): Wer ist Yum-Yum? Ein Cartoon-Staat im Werden. Pp. 245-279 in: Steffen Roth / Lukas Schreiber / Ralf Wetzel (eds.), Organisation multimedial. Zum polyphonen Programm der nächsten Organisation. Heidelberg: Carl-Auer-Verlag.

Baecker, Dirk (1999): The form game. Pp. 99-106 in: Dirk Baecker (ed.), Problems of form. Stanford, Cal.: Stanford University Press.

Bateson, Gregory (1955): The message »This is play«. Pp. 45-242 in: Bertram Schaffner (ed.), Group processes. Transactions of the second conference October 9, 10, 12, 1955, Princeton. N.J. New York: Josiah Macy JR Foundation.

Bjerg, Helle/Knudsen, Hanne (2012): Når personkendskab bliver professionskundskab. Pp. 76-97 in: Margaretha Järvinen/Nanna Mik-Meyer (ed.), At skabe en professionel. København: Hans Reitzels forlag.

Derrida, Jacques (1988): The ear of the other. London: University of Nebraska Press.

Derrida, Jacques (1992): The gift of death. London: University of Chicago Press. 
Derrida, Jacques (2007): Des tours de Babel. Pp. 191-225 in: Jacques Derrida: Psyche. Inventions of the other. Vol. 1. Stanford, Cal.: Stanford University Press.

Hattie, John (2009): Visible Learning. A synthesis of over 800 meta-analyses relating to achievement. London/New York: Routledge.

Hedegaard, Jespersen / Mikkelsen, Haarder/Møller, Frederiksen et al. (2008): Fællesskab forudsætter personligt ansvar. Politiken, 25.11. 2008.

Højlund, Holger/Lars Thorup, Larsen (2001): Det sunde fællesskab. Distinktion 3, 73-90.

Kierkegaard, Søren (1946): Either/or. Vol. 2. London: Oxford University Press.

Kierkegaard, Søren (1988): Enten-Eller. København: Gyldendals Klassikere.

Knudsen, Hanne (2009): The betwixt and between family class. Nordic Educational Review 29, 149-162.

Knudsen, Hanne (2010): Har vi en aftale? Nyt fra Samfundsvidenskaberne. Frederiksberg.

Knudsen, Hanne (2011): The Game of Hospitality. Ephemera 11, 4, 433-449.

Knudsen, Hanne/Andersen, Niels Åkerstrøm (2014): Playful Hyper Responsibility: toward a dislocation of parents' responsibility. Journal of Education Policy 29, 1, 105129 (DOI:10.1080 / 02680939.2013.791929).

Luhmann, Niklas (1987): The morality of risk and the risk of morality. International Review of Sociology 23, 3, 87-101.

Luhmann, Niklas (1990): Political theory in the welfare state. New York: Walter de Gruyter.

Luhmann, Niklas (1993): The code of moral. Cardozo Law Review 14, 995-1009.

Luhmann, Niklas (1995): Social systems. Stanford, Cal.: Stanford University Press.

Luhmann, Niklas (1996): Membership and motives in social systems. Systems Research 13, 3, 341-348.

Michailakis, Dimitris / Schirmer, Werner (2010): Agents of their health? How the Swedish welfare state introduces expectations of individual responsibility. Sociology of Health \& Illness 32, 6, 1-18.

National Board of Health (2007): Socialt udsatte borgeres sundhed - barrierer, motivation og muligheder. www.leddigsund.dk.

Stäheli, Urs (2003): The popular in the political system. Cultural Studies 17, 2, 275-299.

Stichweh, Rudolf (1997): Professions in modern society. International Review of Sociology 7, 1, 95-102.

Prof. Niels Åkerstrøm Andersen

Department of Management, Politics and Philosophy

Copenhagen Business School (CBS)

Porcelænshaven 18A, DK-2000 Frederiksberg

na.mpp@cbs.dk

Assoc. Prof. Hanne Knudsen

Danish School of Education (DPU)

Aarhus University

Tuborgvej 164, DK-2400 Copenhagen NV.

hakn@dpu.dk 
Copyright of Soziale Systeme is the property of Lucius \& Lucius Verlagsgesellschaft mbH and its content may not be copied or emailed to multiple sites or posted to a listserv without the copyright holder's express written permission. However, users may print, download, or email articles for individual use. 